Article

\title{
Polymeric Nanoparticle Associated with Ceftriaxone and Extract of Schinopsis Brasiliensis Engler against Multiresistant Enterobacteria
}

\author{
Maísa Soares de Oliveira ${ }^{1}$, João Augusto Oshiro-Junior ${ }^{1, *}$, Mariana Rillo Sato ${ }^{2}$, \\ Marta Maria Conceição ${ }^{3}$ and Ana Cláudia Dantas Medeiros ${ }^{1, *}$
}

1 Laboratório de Desenvolvimento e Ensaios de Medicamentos, Centro de Ciências Biológicas e da Saúde, Universidade Estadual da Paraíba, R. Baraúnas, 351, Cidade Universitária, 58429-500 Campina Grande, Paraíba, Brasil; maisasoaresdo@gmail.com

2 Faculdade de Ciências Farmacêuticas, Universidade Estadual Paulista Júlio de Mesquita Filho, Araraquara-Jaú, 14.800-903 Km 1 Araraquara, São Paulo, Brazil; rillosato@gmail.com

3 Centro de Tecnologia e Desenvolvimento Regional, Universidade Federal da Paraíba, Av. dos Escoteiros, s/n, Mangabeira VII, 58055-000 João Pessoa, Paraíba, Brasil; marta.conceicao@academico.ufpb.br

* Correspondence: joaoaugustooshirojunior@gmail.com (J.A.O.-J.); anaclaudia@uepb.edu.br (A.C.D.M.); Tel.: +55-83-3315-3300 (ext. 3526) (J.A.O.-J.)

Received: 18 June 2020; Accepted: 16 July 2020; Published: 23 July 2020

\begin{abstract}
Bacterial resistance has become an important public health problem. Bacteria have been acquiring mechanisms to resist the action of antimicrobial active pharmaceutical ingredients (API). Based on this, a promising alternative is the use of nanotechnology, since when the systems are presented in nanometric size, there is an increase in the interaction and concentration of the action at the target site improving the activity. Thus, this study aims to develop a polymeric nanoparticle (PN) composed of chitosan and hydroxypropylmethylcellulose, as an innovative strategy for the administration of an association between ceftriaxone and extract of $S$. brasiliensis, for the treatment of Enterobacteriaceae. From a Box-Behnken design, nanoparticles were obtained and evaluated using the DLS technique, obtaining the particle size between 440 and $1660 \mathrm{~nm}$, IPD from 0.42 to 0.92 , and positive charges. Morphological characteristics of PN by SEM revealed spherical morphology and sizes similar to DLS. Infrared spectroscopy showed no chemical interaction between the components of the formulation. The broth microdilution technique evaluated their antimicrobial activity, and a considerable improvement in the activity of the extract and the API compared to the free compounds was found, reaching an improvement of 133 times in the minimum inhibitory activity CRO.
\end{abstract}

Keywords: bacterial resistance; Enterobacteriaceae; chitosan; HPMC

\section{Introduction}

Bacterial resistance to available antibiotics causes about 700 thousand deaths per year, according to data obtained by the World Health Organization (WHO), however, it is estimated that this number will increase considerably, reaching 10 million deaths per year by 2050, which makes it a major public health problem [1]. Besides, this resistance will have economic implications because studies show the world may lose between 60 and 100 trillion dollars in economic production, which represents a decrease of 2.0 to $3.5 \%$ of global gross domestic product (GDP) expected for 2050 [2,3].

The adaptive capacity of bacteria through the development of resistance mechanisms allows them to remain in activity even when in contact with antibiotic substances and this happens because bacteria can regulate the expression of genes and determinants of resistance, preventing the active pharmaceutical ingredients (API) to act effectively [4]. 
The vast majority of bacterial species can express resistance genes, however, the Enterobacteriaceae family is considered a special treat, since is a family that has a large number of genera and species, among them the most commonly isolated in clinical cultures, including Escherichia coli, Klebsiella pneumoniae, and Enterobacter aerogenes, often relating to infections acquired in the Community and the hospital environment [5].

The Enterobacteriaceae is a family of Gram-negative, facultative anaerobic bacteria that do not form spores, they leave a wide range of carbohydrates, have a complex antigenic structure, and produce a variety of toxins and other virulence factors. Some enteric organisms are part of the normal microbiota and eventually cause disease, but others are regularly pathogenic to humans [6,7].

Infections caused by bacteria belonging to this family are mainly treated with antibiotics belonging to the beta-lactam group. This group includes penicillins, cephalosporins, monobactams, and carbapenems which are the most frequently prescribed antibiotics worldwide. These agents bind to and inhibit bacterial enzymes (referred to as penicillin-binding proteins) responsible for cell wall synthesis. However, enterobacteria have the ability to produce beta-lactamases, which are enzymes that promote the degradation of beta-lactam rings through hydrolysis, inactivating the antibiotics of this class [8].

The $\beta$-Lactamases differ from each other in their substrate profiles (the different types of $\beta$-lactam antibiotics they inactivate), inhibitor profile (which compounds inactivate them), and sequence homology (amino acid composition of these enzymes). The extended-spectrum beta-lactamases (ESBL) are capable of hydrolyzing penicillins, cephalosporins including third generation and monobactams, while carbapenemases inactivate the classes, fourth-generation cephalosporins, and carbapenems. Thus, infections caused by bacteria producing these enzymes are hardly treated due to the few therapeutic options $[5,9,10]$.

Due to this important ability that bacteria have to acquire resistance, and the difficulty of producing new antibacterial substances drives world governments to recognize the need to seek innovative solutions to combat this public health problem [11]. Several studies using plant extracts have been conducted based on popular knowledge. Among the species studied, S. brasiliensis revealed numerous pharmacological and antimicrobial activity $[12,13]$. In addition, other studies evaluated multiresistant microorganisms and observed the modulating effect of the extract with various antibiotics, improving their response [14,15]. These numerous pharmacological proprieties may be due to the bioactive compounds present in this species, which include tannins and polyphenols, such as methyl gallate, gallic acid, and ellagic acid [16-19].

Another idea to improve the treatment of infections is the use of nanotechnology, since it is possible with nanoencapsulation to modify the activity of antibiotics already available in the market that had their action decreased due to resistance mechanisms presented by bacteria [20].

When the systems are in nanometric size and the surface charges are adequate, they promote an increase in the interaction and concentration of the active in the target site, protecting the API from enzymatic degradation, in addition to improving their penetration into the mucosal epithelium, modulating the pharmacokinetics of API and thus improving their effectiveness and reducing toxicity [21-27].

Based on this, the polymeric nanoparticles (PNs) have become an important alternative against bacterial resistance, since they can recover the effectiveness of drugs to which bacteria already have resistance, overcoming mechanisms such as degradation by beta-lactamase, efflux pumps or difficulty to cross broad cell walls. Additionally, PNs are less likely to induce resistance when compared to free active pharmaceutical ingredients(API) [28].

Therefore, this study aimed at developing and characterizing a polymeric nanoparticle associated with ceftriaxone and extract of leaves of S. brasiliensis, for the treatment of enterobacteria producing ESBL and KPC. 


\section{Materials and Methods}

\subsection{Materials}

Chitosan (LMWC) and colloidal silicon dioxide (MW $=60.08 \mathrm{~g} \mathrm{~mol}^{-1}$ ) were purchased from Henrifarma Produtos Químicos e Farmacêuticos Ltd. (Cambuci, Brazil). Hydroxypropyl methylcellulose $\left(\mathrm{MW}=1261.45 \mathrm{~g} \mathrm{~mol}^{-1}\right)$ from Unna Derme Comércio de Produtos Farmacêuticos Ltd. (Campina Grande, Brazil).

\subsection{Plant Material}

The leaves of Schinopsis brasiliensis Engler were collected in the semiarid region of Paraíba, Brazil $\left(70^{\circ} 13^{\prime} 50^{\prime} \mathrm{S}, 35^{\circ} 52^{\prime} 52^{\prime} \mathrm{W}\right)$. The Macro and microscopic botany identification were performed in the Herbarium Jaime Coelho de Moraes in the Center of Agricultural Sciences of the federal university of Paraiba (UFPB) and the exsiccate was deposited with registration number EAN-14049. The access to the plant was registered in the National System of Genetic Heritage and Associated Traditional Knowledge (SISGEN) under the number A0AAB55.

\subsection{Obtaining the of S. brasiliensis Extracts}

To obtain the extracts, the plant drug was cleaned and dried in a drying oven by forced air circulation at $40{ }^{\circ} \mathrm{C}$, until constant weight and pulverized in a knife mill with an output of 10 mesh. After the processing, the plant drug was stored in Kraft paper bags. Dry residue and extraction yield was determined by analysis, as described in the Brazilian Pharmacopeia 5th Edition [29].

The hydroalcoholic extract was obtained by the maceration method, using as solvent a hydroalcoholic solution $70 \%(\mathrm{v} / \mathrm{v})$. After this step, the extract was dried in a spray dryer using as pharmaceutical stabilizer aerosol $200^{\circledR} 20 \%$, which was calculated concerning the dry residue. For the nebulization of the extract was used $120^{\circ} \mathrm{C}$ as input temperature and between 90 and $95^{\circ} \mathrm{C}$ as output temperature, with a feed flow of $7 \mathrm{~mL} \mathrm{~min}^{-1}$.

The dried extracts were stored in hermetically sealed vials under a temperature of $20{ }^{\circ} \mathrm{C}$ until further analysis.

\subsection{Development of Polymeric Nanoparticles}

Polymeric nanoparticles (PN) were developed according to the polyelectrolytic complexation methodology, using a cationic charge polymer (chitosan (CS)) and an anionic charge polymer (HPMC) according to Boni et al. [30], CS was dispersed in $0.1 \mathrm{~mol} \mathrm{~L}^{-1}$ acetic acid, while HPMC was dispersed in distilled water obtaining in both, a final concentration of $2 \mathrm{mg} \mathrm{mL}^{-1}$. The $\mathrm{pH}$ of the solutions were obtained with the aid of a pHmeter Mylabor (OA210A) brand and the adjustment was performed by dripping an alkaline solution of $\mathrm{NaOH} 1 \mathrm{M}$, to obtain a final $\mathrm{pH}$ of 5.5. To eliminate possible agglomerates of particles, a polymeric solution was filtered using $0.25 \mu \mathrm{m}$ filters Millipore brand.

Then, the PNs were obtained by placing the API and the dried extract in the dispersion of the polymers with great volume (Table 1), followed by the slow addition, with the aid of a $12.7 \mathrm{~mm}$ syringe and needle, of the polymer dispersion of opposite charge under magnetic stirring for $15 \mathrm{~min}$, at room temperature $\left(25^{\circ} \mathrm{C}\right)$. 
Table 1. Composition of formulations based on the independent variables. $\mathrm{X} 1-$ concentration of polymers (\%), X2-API concentration (\%), and X3-extract concentration (\%).

\begin{tabular}{cccc}
\hline & $\mathbf{X 1}$ & $\mathbf{X} \mathbf{1}$ & $\mathbf{X 3}$ \\
\cline { 2 - 4 } Formulations & HPMC/CS & CRO & EX \\
\cline { 2 - 4 } & $\mathbf{( \% )}$ & $\mathbf{( \% )}$ & $\mathbf{( \% )}$ \\
\hline NP-1 & $70 / 30$ & 1 & 2 \\
NP-2 & $70 / 30$ & 3 & 2 \\
NP-3 & $70 / 30$ & 2 & 1 \\
NP-4 & $70 / 30$ & 2 & 3 \\
NP-5 & $30 / 70$ & 1 & 2 \\
NP-6 & $30 / 70$ & 3 & 2 \\
NP-7 & $30 / 70$ & 2 & 1 \\
NP-8 & $30 / 70$ & 2 & 3 \\
NP-9 & $50 / 50$ & 1 & 1 \\
NP-10 & $50 / 50$ & 1 & 3 \\
NP-11 & $50 / 50$ & 3 & 1 \\
NP-12 & $50 / 50$ & 3 & 3 \\
NP-13 & $50 / 50$ & 2 & 2 \\
NP-14 & $50 / 50$ & 2 & 2 \\
NP-15 & $50 / 50$ & 2 & 2 \\
\hline
\end{tabular}

\subsection{Experimental Design Box-Behnken}

The optimization of the PNs formulation process was performed through an experimental design of Box-Behnken type using three independent variables: concentration of polymers (X1), API concentration (X2) and extract concentration (X3), which were established at high, medium, and low levels (Table 2), totaling 12 runs with three repetitions at the midpoint to obtain the dependent variable (response): particle size. The Statistica 10 software (StatSoft, version 10.0.228.8) was used to generate the planning matrix.

Table 2. The Box-Behnken $\left(3^{3}\right)$ factorial and levels design using three independent variables. X1-Concentration of polymers (\%), X2-API concentration (\%) and X3-extract concentration (\%), which were established at high, medium, and low levels.

\begin{tabular}{cccc}
\hline \multirow{2}{*}{ Variables } & \multicolumn{3}{c}{ Level } \\
\cline { 2 - 4 } & $\mathbf{- 1}$ & $\mathbf{0}$ & $\mathbf{1}$ \\
\hline $\mathrm{X}_{1}$ & $30 / 70$ & $50 / 50$ & $70 / 30$ \\
$\mathrm{X}_{2}$ & 1 & 2 & 3 \\
$\mathrm{X}_{3}$ & 1 & 2 & 3 \\
\hline
\end{tabular}

\subsection{Physicochemical Characterization of Nanoparticles}

\subsubsection{Analysis of Particle Size, Polydispersity Index (PDI) and Zeta Potential (ZP)}

To determine the particle size and the PDI was used dynamic light scattering technique (DLS) and to determine the $\mathrm{ZP}$ has used the electrophoretic mobility technique, both with the aid of Zetasizer equipment Nano-ZS at $25^{\circ} \mathrm{C}$, at a detection angle of $173^{\circ}$. The nanoparticles were placed in the sample port and the readings were made in triplicate.

\subsubsection{Morphological Analysis of Nanoparticles}

Morphological analysis of nanoparticles was performed by high-resolution scanning electron microscopy (SEM-FEG) technique, model JSM-7500F (JEOL Brazil, São Paulo, SP, Brazil), with operating software PC-SEM with secondary electron detectors, backscattering and chemical analysis (energy dispersive spectroscopy (EDS)) Thermo Scientific, model Ultra Dry, with operating software NSS 2.3. 
The samples were diluted in the ratio 1:50 (v/v) in Tween $20(0.5 \% \mathrm{v} / \mathrm{v})$ to avoid agglomeration of particles, and $7 \mu \mathrm{L}$ added on a silicon metal plate of $1 \mathrm{~cm}^{2}$ mand taken to desiccator, where they remained for three days at room temperature. Subsequently, the support containing the sample was coated with carbon using the equipment BAL-TEC SCD 050 (sputter coater), with associations of mechanical pumps and turbo brand Edwards model t-station 75, for reading the analysis.

\subsubsection{Fourier Transform Infrared Spectroscopy (FTIS)}

The tests were performed with a Shimadzu spectrophotometer IR prestige-21 model, in the region of $4000-400 \mathrm{~cm}^{-1}$. The resolution of analysis was $4 \mathrm{~cm}^{-1}$ and the samples were dispersed in $\mathrm{KBr}$ (degree of spectroscopic purity) in the ratio $1: 100 \mathrm{mg}$ for making tablets of $1.2 \mathrm{~cm}$ in diameter.

\subsection{Antimicrobial Activity}

The determination of the Minimum Inhibitory Concentration (MIC) of the extract of S. brasiliensis (EX) and ceftriaxone (CRO) was performed against strains of enterobacteria with different sensitivity profiles. For this, we used a strain of Escherichia coli ATCC 25,922 (B01) and clinical strains from the collection of a private laboratory network of Campina Grande, with known sensitivity profile, being an Escherichia coli producing ESBL (B02) and a carbapenemase-producing Klebsiella pneumoniae (KPC) (B03). To determine the MIC was used the broth microdilution technique, as described by the Clinical Laboratory and Standards Institute.

To perform the test, the inoculum was standardized in a spectrophotometer at a wavelength of $625 \mathrm{~nm}$ to obtain the correct optical density of turbidity control, which must vary from 0.08 to 0.10 to obtain the standard McFarland solution of 0.5 , resulting in a suspension containing approximately 1 to $2 \times 10^{8} \mathrm{CFU} \mathrm{mL}{ }^{-1}$. To obtain a final concentration of $5 \times 10^{6} \mathrm{CFU} \mathrm{mL}^{-1}$ a dilution of 1:20 was performed in the suspension obtained.

The extracts were diluted in 10\% dimethylsulfoxide (DMSO) at concentrations of 1000 to $7.8 \mu \mathrm{g} \mathrm{mL} \mathrm{m}^{-1}$, while a solution of ceftriaxone was obtained and diluted from 1000 to $0.48 \mu \mathrm{g} \mathrm{mL}^{-1}$. One hundred microliters of each extract and ceftriaxone were added in the wells of the microplate, containing the broth $80 \mu \mathrm{L}$ Mueller Hinton and $20 \mu \mathrm{L}$ of the adjusted inoculum, resulting in a final concentration $5 \times 10^{5} \mathrm{CFU} \mathrm{mL}^{-1}$. The plates were incubated at $35 \pm 2{ }^{\circ} \mathrm{C}$ for $20 \mathrm{~h}$.

The MIC was defined as the lowest concentration that inhibited visible microbial growth, confirmed after the addition of $20 \mu \mathrm{L}$ of resazurin in each well of the plate. The analyses were performed in triplicate. In parallel, the viability of the strain (growth control) and the sterility control of the medium was performed.

The determination of the MIC of PN was obtained following the methodology described in topic 4.3. Pure nanoparticles, nanoparticles containing only 3\% API, nanoparticles containing 3\% extract, and the formulation chosen according to the results obtained by characterization were tested. From the results obtained by the MIC, it was determined the minimum bactericidal concentration (MBC). With the aid of the platinum loop, $1 \mu \mathrm{L}$ was removed from the well and seeded in Petri dishes with Mueller Hinton agar. The plates were incubated at $35 \pm 2{ }^{\circ} \mathrm{C}$ for $24 \mathrm{~h}$. After this, it was possible to observe whether there was bacterial growth.

\section{Results and Discussion}

\subsection{Evaluation of S. brasiliensis Extract}

The dry residue of the extract was determined according to what is described in the Brazilian Pharmacopoeia V Edition (2010) [29] being obtained $64 \mathrm{~g}$ of $200 \mathrm{~mL}$ of the macerated extract. $12.8 \mathrm{~g}$ of the aerosol $200{ }^{\circledR}$ stabilizer were added, which represents $20 \%$ of the dry residue mass, resulting in a theoretical mass of $76.8 \mathrm{~g}$. After drying the extract containing the stabilizer, a mass of $67.0 \mathrm{~g}$ of the dry extract was obtained, which represented an extraction yield of $87.2 \%$. 


\subsection{Development of Nanoparticles}

The polyelectrolytic complexation was the chosen technique, since it has advantages, such as the ease of two polymers of opposite charges complex without the need for reaction initiators, catalysts, or crosslinking. The elimination of these additives makes most complexes nontoxic and easy to manufacture, and this reduces the cost of research and development of drug compounds [31].

Thus, it was determined that the optimization of obtaining the nanoparticles would be done using the experimental design of the Box-Behnken type, since experimental designs are useful for the development of formulations, because from them less a smaller amount of experiments are needed in relation to pharmacotechnical development empirically, and provide information that correlates the independent and dependent variables [32].

The combinations between the independent variables (HPMC/CS, CRO, and EX) generated the planning matrix and from this, 15 formulations were prepared, three of them repetitions at the central point. Table 1 shows the composition of the formulations based on the independent variables. According to the planning matrix generated from the software Statistic 10 , the PN were prepared by varying the concentrations of the polymers so that the upper level had a predominance of CS (70\%) and the complete volume with HPMC (30\%), the low level, the inverse, and the average level equal amounts of the two polymers.

The amount of API and extract added in the PN was equivalent to $3 \%, 2 \%$, and $1 \%$ of the total polymer value in the preparations. Figure 1 shows the visual aspects of all formulations developed according to the planning matrix.

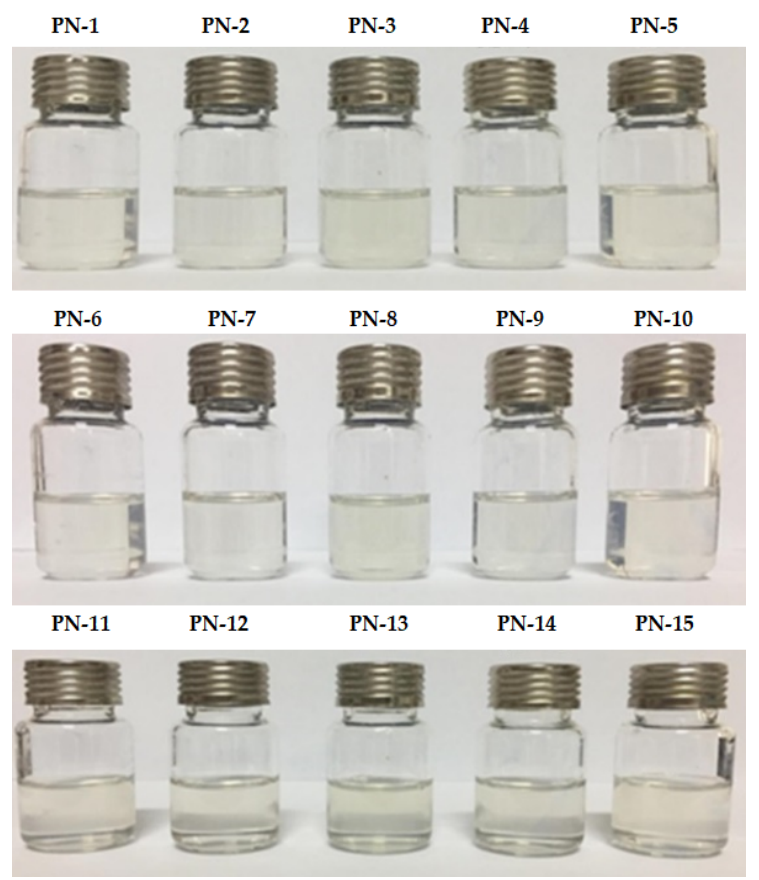

Figure 1. Visual characteristics of polymeric nanoparticles obtained according to the planning matrix.

The obtained nanoparticles showed homogeneity, revealing that it was possible to incorporate 3\% $(\mathrm{w} / \mathrm{w})$ of ceftriaxone and extract with the polymer mass without observing the presence of precipitates or agglomerates. However, due to the formulations present extract in its composition, it was possible to observe a slight change in the shade from transparent to light green, which is due to the color of the extract of the leaves of $S$. brasiliensis in the meantime, where transparency has been maintained. Visually, no formulation showed unwanted organoleptic characteristics.

Using the polyelectrolytic complexation technique to obtain nanoparticles containing curcumin, Tan et al. [33] obtained similar results. Initially, it was prepared with a chitosan solution and another 
with curcumin that was dispersed in the first, followed by drip Arabic gum solution, managing to incorporate $4 \%(\mathrm{~m} / \mathrm{m})$ of the bioactive compound curcumin.

Thus, subsequently, these formulations followed for physicochemical characterization to obtain answers for processing the Box-Behnken design and selection of the formulation for the sequence of experiments.

\subsection{Dynamic Light Scattering, Zeta Potential, and Experimental Design}

The dynamic light scattering (DLS) technique is often used to determine the size of PN. The colloidal suspension is illuminated by a monochromatic laser light that is scattered in a photon detector. Due to the particles present Brownian motion, the intensity of the scattered light detected fluctuates in time and this is related to the size of the particles $[34,35]$. The results of particle size, PDI and zeta potential are shown in Table 3.

Table 3. Results of particle size, polydispersity index (PDI) and zeta potential for the PN measured after preparation, $n=3$.

\begin{tabular}{ccccc}
\hline Acronym & Formulation & d.nm $(\mathbf{n m})$ & PDI & ZP \\
\hline PN1 & HPMC_CS 70/30 C-B 1/2 & $440 \pm 2.13$ & $0.42 \pm 4.13$ & $18.15 \pm 11.20$ \\
PN2 & HPMC_CS 70/30 C-B 3/2 & $497 \pm 1.93$ & $0.58 \pm 10.0$ & $21.10 \pm 0.82$ \\
PN3 & HPMC_CS 70/30 C-B 2/1 & $494 \pm 0.47$ & $0.50 \pm 2.08$ & $22.85 \pm 2.16$ \\
PN4 & HPMC_CS 70/30 C-B 2/3 & $486 \pm 0.82$ & $0.47 \pm 8.41$ & $23.70 \pm 0.59$ \\
PN5 & HPMC_CS 30/70 C-B1/2 & $546 \pm 0.38$ & $0.69 \pm 11.00$ & $22.15 \pm 2.87$ \\
PN6 & HPMC_CS 30/70 C-B 3/2 & $554 \pm 1.04$ & $0.42 \pm 6.12$ & $22.20 \pm 2.54$ \\
PN7 & HPMC_CS 30/70 C-B 2/1 & $628 \pm 1.77$ & $0.61 \pm 12.70$ & $23.70 \pm 0.59$ \\
PN8 & HPMC_CS 30/70 C-B 2/3 & $632 \pm 1.57$ & $0.47 \pm 5.49$ & $27.50 \pm 10.10$ \\
PN9 & HPMC_CS 50/50 C-B 1/1 & $776 \pm 6.92$ & $0.42 \pm 11.30$ & $23.10 \pm 3.67$ \\
PN10 & HPMC_CS 50/50 C-B 1/3 & $713 \pm 3.54$ & $0.58 \pm 18.80$ & $22.65 \pm 2.80$ \\
PN11 & HPMC_CS 50/50 C-B 3/1 & $655 \pm 14.14$ & $0.62 \pm 24.30$ & $22.10 \pm 1.91$ \\
PN12 & HPMC_CS 50/50 C-B 3/3 & $1094 \pm 8.22$ & $0.64 \pm 6.23$ & $22.00 \pm 6.42$ \\
PN13 & HPMC_CS 50/50 C-B 2/2 & $1430 \pm 7.31$ & $0.91 \pm 5.38$ & $38.95 \pm 5.99$ \\
PN14 & HPMC_CS 50/50 C-B 2/2 & $1660 \pm 10.90$ & $0.90 \pm 7.43$ & $26.05 \pm 4.07$ \\
PN15 & HPMC_CS 50/50 C-B 2/2 & $1275 \pm 5.09$ & $0.92 \pm 9.05$ & $26.05 \pm 4.07$ \\
\hline
\end{tabular}

The particle size values obtained were placed in the planning matrix generated by the software (Statistical 10.0) obtaining then the Pareto diagram with the estimated effects of the variables tested about the size of PN (Figure 2). The result showed that only the quadratic portion of polymer in the upper level interfered in the size of the particles tested, which indicates that the increase in the concentration of chitosan in the formulation influences the particle size. However, it was observed a lack of adjustment in the model. Thus, the model is not suitable to generate the response surface graphs with accuracy.

However, these results corroborate the data found by dynamic light scattering technique (Table 3), in which it is possible to verify that the chitosan in the proportion of $30 \%$ presents average diameter values (d.nm) between $440 \pm 2.1$ and $497 \pm 1.9 \mathrm{~nm}$. While the formulations contained chitosan in the proportion of $50 \%$ and $70 \%$, the values are greater than $500 \mathrm{~nm}$. In agreement with the results found, studies conducted by Zaki and Hafez [36], observed larger PN sizes related to the increase in the proportion of chitosan, reaching a variation of $152 \mathrm{~nm}$, since the ratio $5 / 1 \mathrm{of} C \mathrm{~S} / \mathrm{TPP}$ at $\mathrm{pH} 4$ the average particle size was $128 \mathrm{~nm}$ which was increasing the measure that increased the proportion of chitosan reaching $280 \mathrm{~nm}$.

The formulations named as PN12, PN13, PN14 and PN15 the values of d. nm were $1094 \pm 8$, $1430 \pm 7,1660 \pm 10$ and $1275 \pm 5$, respectively, exceeding the nanoscale. Studies by Polexe and Delair [37] with nanoparticles, aiming at the functionalization of antibodies obtained by polyelectrolytic complexation technique using the polymer chitosan and hyaluronic acid showed similar results to those presented in this study, since the particle size ranged between 271 and $1220 \mathrm{~nm}$. Thus, the 
authors attributed the fact that some particles have a larger size (1100 and $1220 \mathrm{~nm})$ by the proportion of polymers used, which led to a neutralization of the charges preventing the formation of the complex.

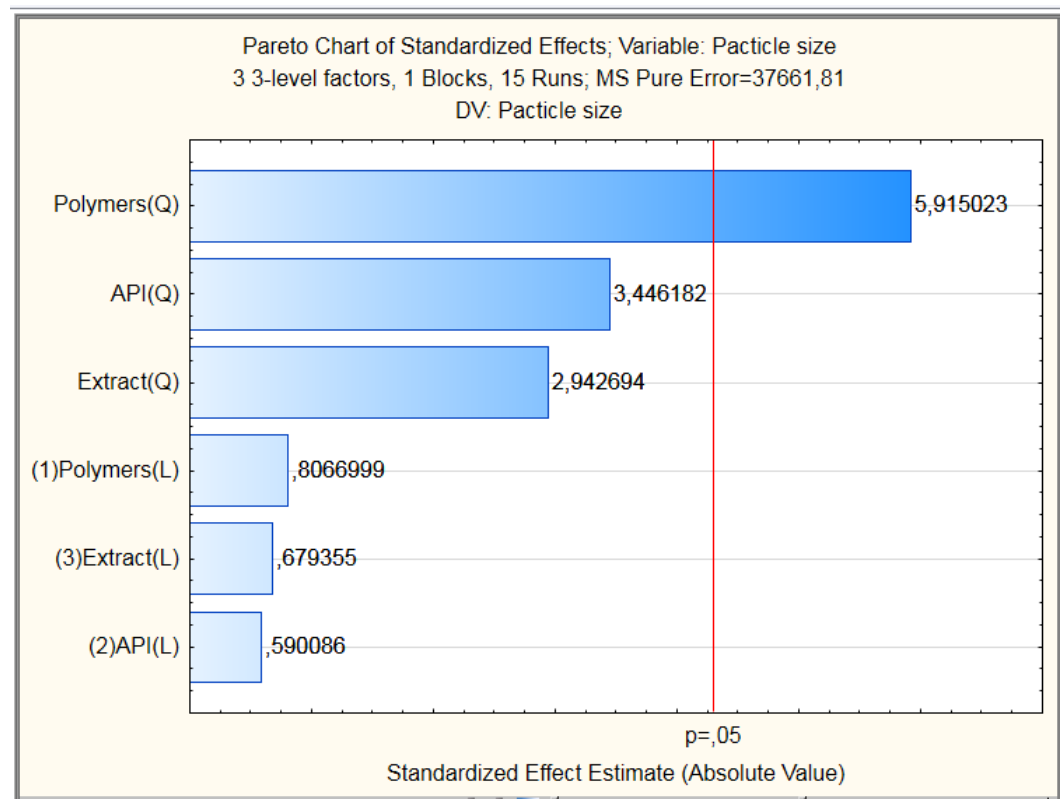

Figure 2. Pareto graph on the influence of the formulation components on the average size.

This hypothesis is consistent for the formulations PN12, PN13, PN14, and PN15, since it was observed that in these formulations obtained with the same proportion of CS/HPMC, a considerable increase in particle size, which may have been due to charge cancellation and absence of PN formation. Moreover, these formulations were discarded for the other experiments.

To obtain PN by polyelectrolytic complexation, Boni et al. [30] used the positive charge polymers chitosan and the negative charge, hyaluronic acid, and HPMC. The PN obtained with and without API showed sizes ranging between 325.7 and 450.5, and zeta potential ranging between \pm 20.9 and \pm 33.1 , which is similar to the results found in the formulations named PN-1, PN-2, PN-3, and PN-4.

In the literature, different studies attribute to the smaller particle size the ability to cross the biological barrier, improving the absorption of API, when there is a reduction in this size. This fact represents numerous advantages, because it improves the bioavailability of the drug, and the length of stay in the infected site, protecting the drug from degradation and achieving a gradual release pattern [38].

Regarding the results of PDI, we can observe that the formulations developed with the lowest concentration of chitosan have fewer variations in the results regardless of the concentration of the mixture API/extract, being between $0.42 \pm 4.13$ and $0.58 \pm 10$. Besides, they have smaller relative deviations when compared to formulations developed with higher concentrations of chitosan $(0.47 \pm 5.49$ and $0.92 \pm 9.05)$, indicating less variation in particle size distribution.

According to Avadi et al. [39], the values of IPD vary between 0 and 1, and values less than 0.5 indicate that the particles have a homogeneous distribution, the particles have a size that does not vary so much about the average, while values above this indicate a more heterogeneous distribution. However, according to current studies conducted by Danaei et al. [40] the values of this index found above 0.7 indicate that the sample has a very wide particle size distribution and is probably not suitable to be analyzed by DLS technique.

The importance of obtaining PN with monomodal distribution is due to its physicochemical properties, since the absence of this distribution can affect the volume properties, product performance, processability, stability and appearance of the final product, and influence cell uptake dependent on endocytosis [40]. The increase of the IPD, which indicates a heterogeneous distribution may be due 
to the presence of aggregates, however, these results should not be analyzed in isolation and it is necessary to combine with other techniques [41].

The ZP values found for all formulations were positive being in a range between $18.15 \pm 11.2$ and $38.95 \pm 5.99$. The positive charges found are due to free amino groups $(-\mathrm{NH} 2)$ of chitosan that become protonated $\left(-\mathrm{NH}_{3}{ }^{+}\right)(\mathrm{pH} 5.5)$ overcoming the negative groups present in HPMC $(-\mathrm{OH})[42,43]$.

This effect may be related to the absorption of anionic groups by the long amino groups of chitosan, keeping high the value of the electrical double layer thickness, which, in turn, prevents aggregation. Because of this, the $\mathrm{ZP}$ is one of the most used parameters to indicate long-term stability, due to repulsion between particles (electrostatic forces) [39].

According to Bhattacharjee [44], the dispersions of $\mathrm{np}$ that have $\mathrm{ZP}$ in the range of $\pm 20-30 \mathrm{mV}$ are considered moderately stable, which allows them to be used in drug administration. Most of the values found in this study are within this range, which allows this classification. Additionally, a study by Ilk et al. [45] evaluated the stability of chitosan np loaded with kaempferol and obtained a ZP range very close to that found in this study, ranging between \pm 18.5 and \pm 38.1 , which observed adequate stability of the product, which was maintained for 30 days.

Based on the results were selected to continue the analysis PN-1, PN-2, PN-3, and PN-4 formulations since they obtained the smallest particle sizes combined with appropriate ZP and PDI.

\subsection{Scanning Electron Microscopy (SEM)}

The chosen formulations were evaluated in SEM. This technique can provide information about the size and morphology of the particles. An electron beam falls on the sample surface to produce a variety of signals that are collected by a detector, resulting in images with high magnification $(50-10,000 \times)$ and resolution from $10 \mathrm{~nm}$ to micrometers [46]. Figure 3 shows the photomicrographs of the nanoparticles.

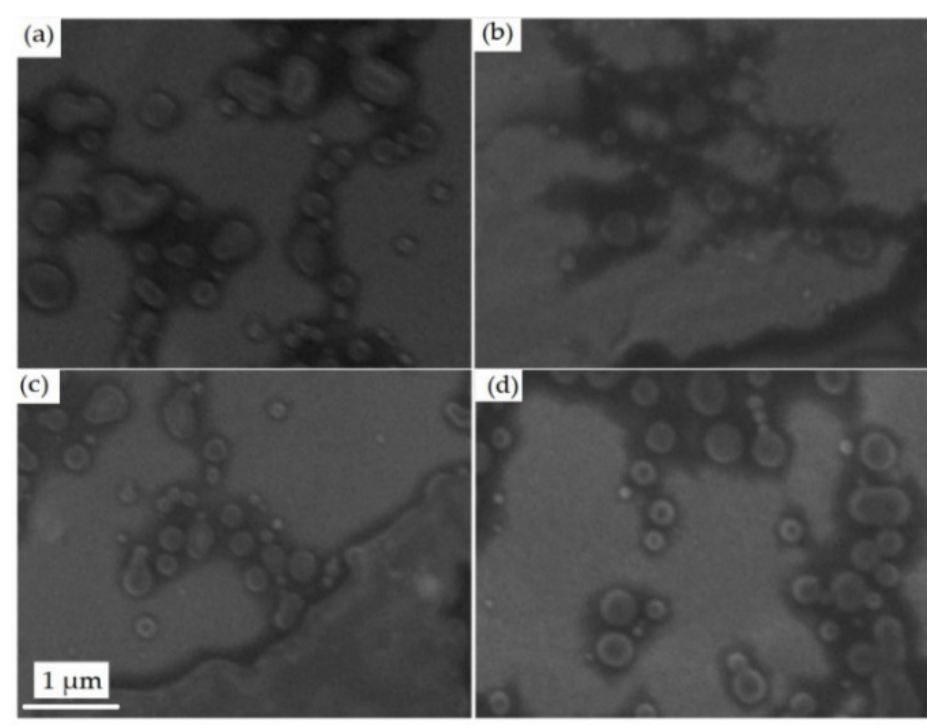

Figure 3. Photomicrographs of polymeric nanoparticles (a) PN-1, (b) PN-2 (c) PN-3, and (d) PN-4. Magnification of 25,000×.

The SEM results show that PN-1 (3a), PN-2 (3b), PN-3 (3c), and PN-4 (3d) have spherical morphology with nanometric sizes between 150 and $500 \mathrm{~nm}$, similar to the sizes found in the DLS particle distribution graph. Due to the lack of contrast between the active and inert components used, it was not possible to distinguish differences between them.

Probably, the API and the extract are trapped inside the PN and/or interacting on the surface by hydrogen bonds. Corroborating what was previously discussed regarding the need for a combination of techniques to evaluate the homogeneity of the sample, from the result obtained in the SEM, it is 
possible to observe that there was no great difference between the sizes of the PN obtained, which differs from the results obtained in the PDI.

The studies of Gaumet et al. [47] compared results obtained in an electronic micromicron with the PDI values. At microscopy, the sizes found ranged between $100 \mathrm{~nm}$ and $1 \mathrm{~nm}$, while by light scattering technique, the average size was $318 \mathrm{~nm}$ with PDI of 0.093 which is considered a low value that would represent monomodal distribution. Based on this information it is important to highlight the need for a combination of techniques to evaluate the morphology of the particles since due to chitosan by a cationic polysaccharide their physicochemical properties vary according to $\mathrm{pH}$.

\subsection{Fourier Transform Infrared Spectroscopy (FTIR)}

FTIR is a vibrational surface chemical analytical technique that measures the intensity of infrared versus the wavelength of light. This technique is used to chemical characterization of materials at the molecular level, since it determines the positions and relative intensities of all absorptions, or peaks, in the infrared region and graphically records them [48,49].

Figure 4 shows the FTIR spectra of the excipients used in the formulation separately, solution of CS (Figure 4a), and HPMC (Figure 4b).

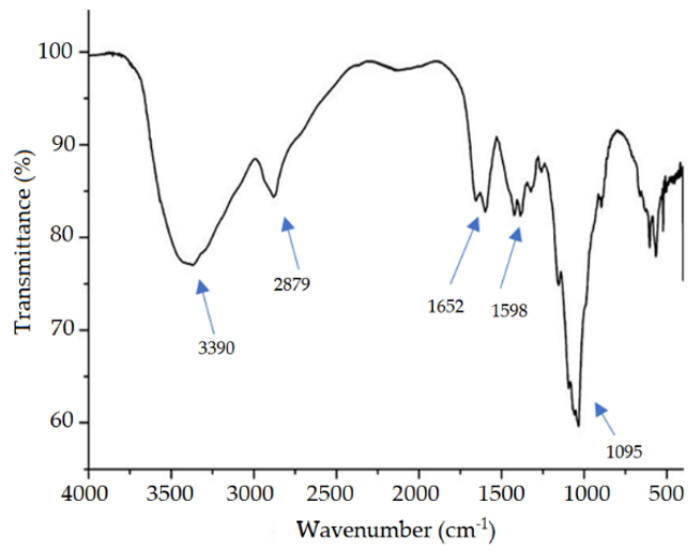

(a)

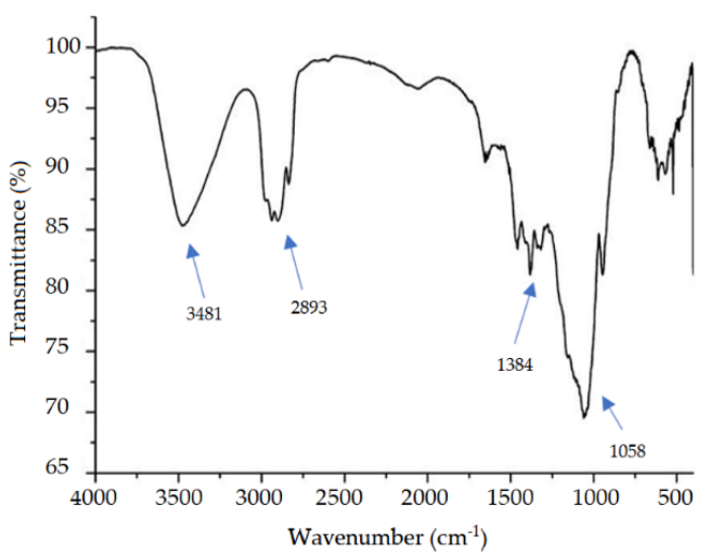

(b)

Figure 4. FTIR spectra for chitosan (a) and hydroxypropylmethylcellulose (b).

In the CS spectrum, it was possible to observe a wide absorption peak in the region of $3390 \mathrm{~cm}^{-1}$ related to the stretching of the $-\mathrm{OH}$ bond, and there may be overlap in the $\mathrm{NH}$ stretch band that occurs between 3500 to $3100 \mathrm{~cm}^{-1}$ [50]. Besides, there is a peak at $2879 \mathrm{~cm}^{-1}$ which corresponds to the stretching of the $\mathrm{C}-\mathrm{H}$ bond of chitosan, and two other peaks at 1652 and $1598 \mathrm{~cm}^{-1}$ which are attributed to primary and secondary amide respectively [51]. Another main band was found ay $1095 \mathrm{~cm}^{-1}$ referring to the $\mathrm{C}-\mathrm{O}$ stretching bond [52].

Analyzing the spectrum of HPMC is possible to observe absorption bands characteristic of this polymer as described in the literature [53]. In the region of $3481 \mathrm{~cm}^{-1}$ was generated broadband that corresponds to the $\mathrm{O}-\mathrm{H}$ connection, while at $2893 \mathrm{~cm}^{-1}$ there is the formation of a peak stretch of $\mathrm{C}-\mathrm{H}$ $\mathrm{sp}^{3}$ and at $1384 \mathrm{~cm}^{-1}$ the peak obtained was related to the folding absorption of $\mathrm{CH}_{3}$. Another peak observed was at $1058 \mathrm{~cm}^{-1}$ which is characteristic of the $\mathrm{C}-\mathrm{O}$ strain [54].

All bands observed in Figure 4 are typical and similar to those described in the literature mentioned above and are present in all commercial samples, revealing that all have the same functional groups.

The spectrum of ceftriaxone (Figure 5a) shows two absorption bands at 3442 and $3253 \mathrm{~cm}^{-1}$ referring to the stretching of the $\mathrm{N}-\mathrm{H}$ group in amides and another main peak at $1735 \mathrm{~cm}^{-1}$ which is due to the stretching of the $\mathrm{C}=\mathrm{O}$ bond of cyclic amide (lactam). At $1652 \mathrm{~cm}^{-1}$ there is a peak that the literature assigns to the oxime that generates the absorption $\mathrm{C}=\mathrm{N}$ and an $\mathrm{O}-\mathrm{H}$ absorption between 
3650 and $2600 \mathrm{~cm}^{-1}$ that is not easily observed due to the overlap of bands. Another peak generated at $1033 \mathrm{~cm}^{-1}$ refers to the $\mathrm{C}-\mathrm{O}$ stretch of the ether [55].

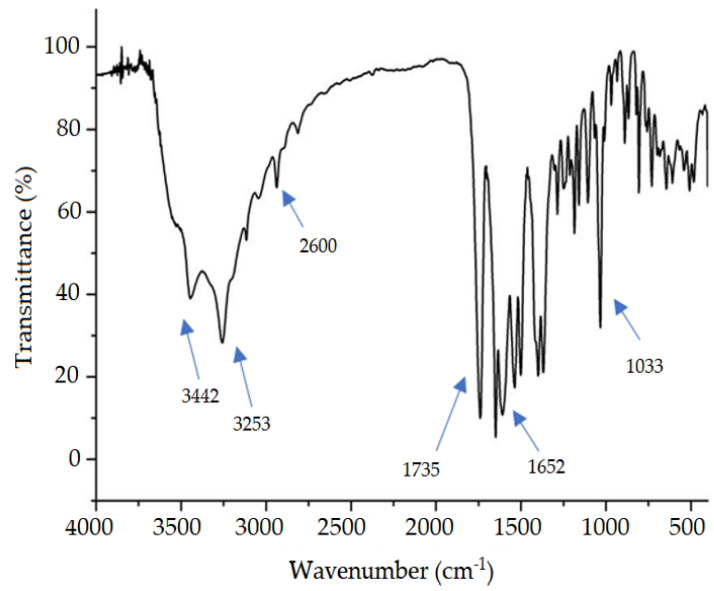

(a)

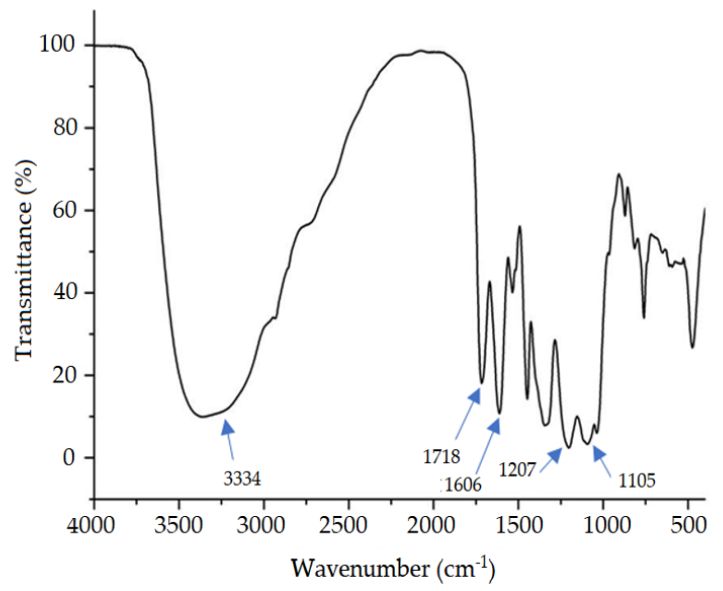

(b)

Figure 5. FTIR spectra for ceftriaxone (a) and extract of S. brasiliensis (b).

Figure $5 \mathrm{~b}$ represents the spectrum of the extract of $S$. brasiliensis which has a wide band at $3334 \mathrm{~cm}^{-1}$, which refers to the stretch of the $\mathrm{O}-\mathrm{H}$ bond. Its presence is justified because the extract is composed of several secondary metabolites, including polyphenols, which are rich in hydroxyl groups [18]. Additionally, at $1718 \mathrm{~cm}^{-1}$ was observed a peak that was attributed to the strain of the bond $\mathrm{C}=\mathrm{O}$ and another related to the bond $\mathrm{C}=\mathrm{C}$ at $1606 \mathrm{~cm}^{-1}$. It is possible to observe two peaks at 1207 and $1105 \mathrm{~cm}^{-1}$ that appear due to the presence of the stretching of the $\mathrm{C}-\mathrm{O}$ bond of the ester, a compound present in flavonoids, such as aglycone, found in this extract [56].

In addition to the spectra of the active and inert components used in the formulation alone, spectra of PN were obtained with and without the extract and the API, to verify whether there was chemical interaction between the components (Figure 6).

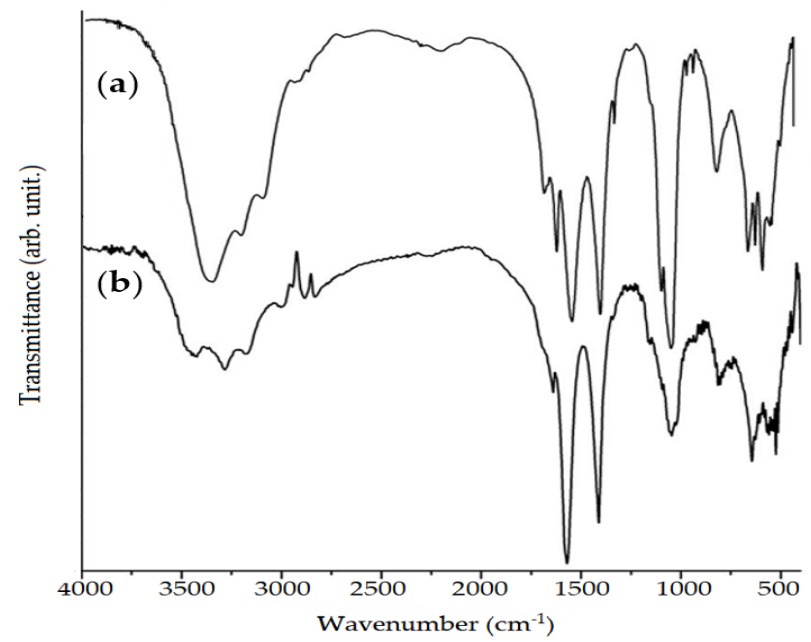

Figure 6. FTIR spectra of the polymeric nanoparticle (PN) (a) and PN containing extract and active pharmaceutical ingredients (API) (PN-4) (b).

From the analysis of the spectra obtained in Figure 6, it is possible to observe that the functional groups found in PN with and without extract and API, (PN-4) are similar, since there was no disappearance of the main absorption peaks, visualized in the inert excipients (Figure 4) and active (Figure 5). The FTIR spectra suggest that there was no appearance of new molecular groups and probably the molecular structure of the activity did not change. 


\subsection{Evaluation of the Antimicrobial Activity of S. brasiliensis and Ceftriaxone}

The extract of S. brasiliensis tested against a standard strain of Escherichia coli by microdilution technique showed inhibitory activity up to a concentration of $250 \mu \mathrm{g}$, however, in the clinical strains producing resistance mechanisms previously known, the extract did not inhibit bacterially. The results obtained from ceftriaxone showed that it was able to inhibit the ATCC strain in the lowest concentration tested, however, only in the highest concentrations there was inhibition of the growth of other bacteria (Table 4).

Table 4. Determination of the MIC of the extract of $S$. brasiliensis and ceftriaxone against strains of Enterobacteriaceae. B01: E. coli ATCC (25922); B02: E. coli extended-spectrum beta-lactamases (ESBL)-producing; B03: K. pneumoniae that produces KPC; EX: extract of S. brasiliensis; CRO: ceftriaxone.

\begin{tabular}{|c|c|c|}
\hline \multirow{2}{*}{ Microorganism Isolated } & EX & CRO \\
\hline & $\operatorname{MIC}\left(\mu \mathrm{g} \mathrm{mL}^{-1}\right)$ & $\operatorname{MIC}\left(\mu \mathrm{g} \mathrm{mL}^{-1}\right)$ \\
\hline B01 & 250 & $<0.5$ \\
\hline B02 & $>1000$ & 1000 \\
\hline B03 & $>1000$ & 500 \\
\hline
\end{tabular}

According to Holetz et al. [57] extracts that have a MIC lower than $100 \mu \mathrm{g} \mathrm{mL}^{-1}$ have excellent antimicrobial activity, while those with MIC between 100 and $500 \mu \mathrm{g} \mathrm{mL}^{-1}$ have moderate activity and values in the range of 500 to $1000 \mu \mathrm{g} \mathrm{mL}^{-1}$ are considered with low activity. Extracts with MIC greater than $1000 \mu \mathrm{g} \mathrm{mL}^{-1}$ are considered inactive. Based on this information, it is possible to observe that the extract of $S$. brasiliensis tested showed moderate antimicrobial activity against B01, since the MIC found was $250 \mu \mathrm{g} \mathrm{mL} \mathrm{m}^{-1}$. However, against strains producing resistance mechanisms the extract was considered inactive (MIC > $1000 \mu \mathrm{g} \mathrm{mL}^{-1}$ ).

Similar results were found by Saraiva et al. [12] who evaluated the extract of S. brasiliensis against different bacterial strains, including and E. coli and K. pneumoniae. It was observed that among the six strains of $E$. coli tested, two of them found MIC of $250 \mu \mathrm{g} \mathrm{mL}^{-1}$, one of $500 \mu \mathrm{g} \mathrm{mL}^{-1}$, and three of $1000 \mu \mathrm{g} \mathrm{mL}^{-1}$, which led the authors to consider the activity of this extract low for this bacterial species. Regarding the strains of K. pneumoniae, it was found that the extract showed no activity, since the MIC found were all higher than $1000 \mu \mathrm{g} \mathrm{mL}^{-1}$.

Accordingly, another study by Formiga Filho et al. [13] evaluated the activity of hydroalcoholic extracts of the bark and leaf of S. brasiliensis. The analyzes were performed against bacterial strains of different species, including E. coli (ATCC 25922), and it was evaluated that the bark extract only inhibited growth at the highest concentration tested $\left(500 \mathrm{mg} \mathrm{mL}^{-1}\right)$, while the leaf extract showed a MIC of $200 \mathrm{mg} \mathrm{mL}^{-1}$, values above the ideal to consider the extract as active.

\subsection{Antimicrobial Activity of Nanoparticles}

Based on the results shown in this study, it was observed that the tested microorganisms that had multidrug resistance showed no sensitivity to the extract, while the MIC found in ceftriaxone was $1000 \mu \mathrm{g} \mathrm{mL}^{-1}$, a value far above the cut-off point $\left(1 \mu \mathrm{g} \mathrm{mL}^{-1}\right)$ to be considered sensitive [58]. Based on the characterization were tested formulations of pure PN, PN with 3\% API (PNF), PN with 3\% extract (PNE), and the chosen formulation (PN4) based on the characterization. The results are described in Table 5 .

When testing the PN formulations the results showed that they had an important antimicrobial activity due to their ability to inhibit bacterial growth as shown in Table 5. It was possible to observe a considerable improvement in the action of encapsulated compared to free API, since the MIC found in B02 microorganism was initially $1000 \mu \mathrm{g} \mathrm{mL}^{-1}$, while in the chosen formulation the MIC found was $7.5 \mu \mathrm{g} \mathrm{mL}{ }^{-1}$ of API, which represents an improvement of 133 times. Similarly, PN was able to inhibit B03 bacteria more effectively than API and free extract. The bacterial strain B01, which is a 
strain of E. coli sensitive to most antibiotics, was also sensitive to all tested formulations, demonstrating that PN has an important bacterial activity both for sensitive strains, as for those that have important resistance mechanisms.

Table 5. MIC determination of the nanoparticles obtained against microorganisms of clinical importance.

\begin{tabular}{cccc}
\hline \multirow{2}{*}{ Formulations } & \multicolumn{3}{c}{ CIM $\left(\mu \mathbf{g ~ m L}^{-\mathbf{1}}\right) /$ Microorganisms Tested } \\
\cline { 2 - 4 } & $\mathbf{B 0 1}$ & $\mathbf{B 0 2}$ & $\mathbf{B 0 3}$ \\
\cline { 2 - 4 } & \multicolumn{3}{c}{$\mathbf{( A P I / E x t r a c t )}$} \\
\hline PNF & $\leq 0.23$ & 7.5 & 15 \\
PNE & $\leq 0.23$ & 15 & 15 \\
PN4 & $\leq 0.15$ & 5 & 10 \\
\hline
\end{tabular}

From the results of the MIC, it was possible to obtain the results of MBC and it was observed that some PNS were able not only to inhibit bacterial growth but also to inactivate bacterial cells, obtaining a bactericidal activity. The results are described in Table 6.

Table 6. Minimum bactericidal concentration $(\mathrm{MBC})$ determination of the nanoparticles obtained against microorganisms of clinical importance.

\begin{tabular}{cccc}
\hline \multirow{2}{*}{ Formulations } & \multicolumn{3}{c}{ MBC $\left(\mu \mathrm{g} \mathrm{mL}^{-\mathbf{1}}\right) /$ Microorganisms Tested } \\
\cline { 2 - 4 } & B01 & B02 & B03 \\
\cline { 2 - 4 } & \multicolumn{3}{c}{ (API/Extract) } \\
\hline PNF & $\leq 0.23$ & 15 & 15 \\
PNE & $\leq 0.23$ & 15 & 30 \\
PN4 & $\leq 0.15$ & 5 & 10 \\
\hline
\end{tabular}

The results show that the MBC values were similar to those found in the MIC, with a difference only in the values found in the NPS, requiring a higher concentration for the bactericidal activity to occur. However, it was observed that there was an improvement in the activity of PN when it contained in its composition the API and the extract in relation to the others. This improvement in activity can be attributed to the antimicrobial capacity that the extract of S. brasiliensis has, and may have been potentiated to be encapsulated in PN along with API, obtaining an improvement in its solubility when compared to the MIC found in the extract alone.

Similarly, studies by Liu et al. [59], developed polymeric nanoparticles containing poly(lactic-co-glycolic acid) (PLGA) to encapsulate the bioactive component curcumin and evaluate its antimicrobial capacity. It was observed that to have a significant reduction in E. coli viability required low concentrations of curcumin compared to the free bioactive and this was due to improved solubility and ability to direct curcumin bacteria.

In addition, PN was also tested, and it was possible to observe inhibitory activity as well as bactericidal activity on the three bacterial strains tested. This activity may be due to the antimicrobial properties previously described as chitosan. Several studies attribute the antimicrobial activity of chitosan to its positive surface charges, which is often reflected in ZP formulations that use this polymer in their composition $[60,61]$.

This antimicrobial activity can happen of two main formals, one is due to the attraction of polycation particles to the negatively charged bacterial surface, which leads to disruption of bacterial membranes, causing leakage of cytoplasmic components. The other occurs because permeation of $\mathrm{PN}$ in the membrane can bind to intracellular components such as DNA, ribosomes, and enzymes, interrupting the normal cellular mechanism, resulting in cell death $[62,63]$.

In this study, PN containing API showed considerably higher antibacterial activity than free API, which may be due to the ability of PN to protect the API from degradation caused by enzymes 
produced by the tested bacteria, improving its bioavailability. In addition, PN can control the release of loaded antimicrobial drugs, which is useful to direct the drug to its site of action [7].

In agreement with the results described here regarding the improvement of encapsulated API activity in relation to free, studies by Jamil et al. [64] evaluated the activity of chitosan PN loaded with cefazolin at concentrations of 200, 800 and $2000 \mathrm{mg} \mathrm{mL}^{-1}$, against Gram-negative bacterial strains, including an E. coli producing ESBL and a multidrug-resistant K. pneumoniae.

It was possible to observe through the agar well diffusion technique that the free cefazolin was not able to form inhibition zone, while the PN showed halos that increased in size as the API concentration in the PN increased. Similarly, the broth dilution technique showed that even at the lowest concentration of API $\left(200 \mu \mathrm{g} \mathrm{mL}^{-1}\right)$ was observed an efficient inhibition of bacterial growth compared to the free API that showed mic of $1000 \mu \mathrm{g} \mathrm{mL}{ }^{-1}$ for E. coli, while for K. pneumoniae was not possible to determine since it was found higher than the tested concentration.

Furthermore, Abdelkader et al. [61] also obtained chitosan PN loaded with an antimicrobial class of beta-lactams, meropenem, and evaluated the inhibitory and bactericidal capacity of these PN compared to API on sensitive and resistant strains of E. coli and K. pneumoniae. It was observed that the dispersion of nanoparticles loaded with API had a MIC twice lower against meropenem sensitive E. coli and meropenem sensitive and resistant K. pneumoniae strains compared to free API meropenem, while the meropenem resistant $E$. coli strain was not significantly different.

\section{Conclusions}

According to the results, it is possible to conclude that the steps of development of nanoparticles, using the technique of polyelectrolytic complexation by drip, and the polymers chitosan and HPMC were suitable since from the physicochemical characterization it was found that the size of the particles obtained was within the acceptable range to be considered nanoparticles. From the antimicrobial activity assays, it was evaluated that the extract of S. brasiliensis, as well as ceftriaxone, showed inhibitory activity only on the strain of E. coli ATCC 25922, while they were not able to inhibit bacterial strains that have resistance mechanisms.

After obtaining the nanoparticles containing the extract and API it was possible to observe an important inhibitory and bactericidal activity on all bacterial strains tested, which demonstrates that nanostructured systems are able to promote improvements in the delivery of API, which make them an important alternative for the treatment of infections caused by multiresistant bacteria.

Author Contributions: Conceptualization, A.C.D.M. and J.A.O.-J.; Methodology, A.C.D.M. and J.A.O.-J.; Formal Analysis, M.R.S. and M.M.C.; Investigation, M.S.d.O.; Writing-Original Draft Preparation, M.S.d.O.; Writing-Review \& Editing, A.C.D.M. and J.A.O.-J.; Supervision, J.A.O.-J.; Project Administration, A.C.D.M.; Funding Acquisition, A.C.D.M. All authors have read and agreed to the published version of the manuscript.

Funding: This research received no external funding.

Acknowledgments: This study was financed in part by the Coordenação de Aperfeiçoamento de Pessoal de Nível Superior-Brasil (CAPES)-Finance Code 001. The authors especially thank Ivan Coelho Dantas (in memoriam) for indicating the plant studied in this work.

Conflicts of Interest: The authors declare no conflict of interest.

\section{References}

1. World Health Organization. No Time to Wait: Securing the Future from Drug-resistant Infections. Available online: https://www.who.int/antimicrobial-resistance/interagency-coordination-group/final-report (accessed on 17 June 2020).

2. Arora, A.; Mishra, A. Antibacterial Polymers-A Mini Review. Mater. Today 2018, 5, 17156-17161. [CrossRef]

3. Viroj, T. Lessons from the Antimicrobial Resistance: From global agenda to national strategic. Bull. World Health Organ. 2017, 95, 599-603. 
4. Shaikh, J.; Ankola, D.D.; Beniwal, V.; Singh, D.; Kumar, M.N.V.R. Nanoparticle encapsulation improves oral bioavailability of curcumin by at least 9-fold when compared to curcumin administered with piperine as absorption enhancer. Eur. J. Pharm. Sci. 2009, 37, 223-230. [CrossRef]

5. Doi, Y.; Paterson, D.L. Carbapenemase-producing Enterobacteriaceae. Semin. Resp. Crit. Care 2015, 36, 74-84.

6. Almugadam, B.S. Prevalence and antibiotics susceptibility patterns of carbapenem resistant Enterobacteriaceae. J. Bacteriol. Mycol. Open Access. 2018, 6, 187-190. [CrossRef]

7. Lakshminarayanan, R.; Ye, E.; Young, D.J.; Li, Z.; Loh, X.J. Recent Advances in the Development of Antimicrobial Nanoparticles for Combating Resistant Pathogens. Adv. Healthc. Mater. 2018, 7, 1-13. [CrossRef] [PubMed]

8. Soontaros, S.; Leelakanok, N. Association between carbapenem-resistant Enterobacteriaceae and death: A systematic review and meta-analysis. Am. J. Infect. Control. 2019, 47, 1200-1212. [CrossRef] [PubMed]

9. Shaikh, S.; Fatima, J.; Shakil, S.; Rizvi, S.M.D.; Kamal, M.A. Antibiotic resistance and extended spectrum beta-lactamases: Types, epidemiology and treatment. Saudi J. Biol. Sci. 2015, 22, 90-101. [CrossRef] [PubMed]

10. Chotiprasitsakul, D.; Srichatrapimuk, S.; Kirdlarp, S.; Pyden, A.D.; Santanirand, P. Epidemiology of carbapenem-resistant Enterobacteriaceae: A 5-year experience at a tertiary care hospital. Infect. Drug Resist. 2019, 12, 461-468. [CrossRef]

11. Lam, S.J.; Wong, E.H.H.; Boyer, C.; Qiao, G.G. Antimicrobial polymeric nanoparticles. Prog. Polym. Sci. 2018, 76, 40-64. [CrossRef]

12. Saraiva, A.M.; Castro, R.H.A.; Cordeiro, R.P.; Peixoto Sobrinho, T.J.S.; Castro, V.T.N.A.; Amorim, E.L.C.; Xavier, H.S.; Pisciottano, M.N.C. In vitro evaluation of antioxidant, antimicrobial and toxicity properties of extracts of schinopsis brasiliensis engl. (Anacardiaceae). Afr. J. Pharm. Pharmacol. 2011, 5, 1724-1731. [CrossRef]

13. Formiga, F.A.L.N.; Carneiro, V.S.M.; Souza, E.A.; Santos, R.L.; Cataõ, M.H.C.V.; Medeiros, A.C.D. In vitro evaluation of antimicrobial photodynamic therapy associated with hydroalcoholic extracts of schinopsis brasiliensis engl: New therapeutic perspectives. Photomed. Laser Surg. 2015, 33, 240-245. [CrossRef] [PubMed]

14. Chaves, T.P.; Fernandes, F.H.A.; Santana, C.P.; Santos, J.S.; Medeiros, F.D.; Felismino, D.C.; Santos, V.L.; Catão, R.M.R.; Coutinho, H.D.M.; Medeiros, A.C.D. Evaluation of the interaction between the Poincianella pyramidalis (Tul.) LP Queiroz extract and antimicrobials using biological and analytical models. PLoS ONE 2016, 11, 4-7. [CrossRef] [PubMed]

15. Soraya, I.; Sulaiman, C.; Basri, M.; Chan, K.W.; Ashari, S.E.; Reza, H.; Masoumi, F.; Ismail, M. In vitro antioxidant, cytotoxic and phytochemical studies of Clinacanthus nutans Lindau leaf extracts. Afr. J. Pharm. Pharmacol. 2015, 9, 861-874.

16. Cardoso, M.P.; David, J.M.; David, J.P. A new alkyl phenol from Schinopsis brasiliensis. Nat. Prod. Res. 2005, 19, 431-433. [CrossRef]

17. Cardoso, M.P.; Lima, L.S.; David, J.P.; Moreira, B.O.; Santos, E.O.; David, J.M.; Alves, C.Q. A new biflavonoid from Schinopsis brasiliensis (Anacardiaceae). J. Braz. Chem. 2015, 26, 1527-1531.

18. Fernandes, F.H.A.; de Batista, R.S.A.; de Medeiros, F.D.; Santos, F.S.; Medeiros, A.C.D. Development of a rapid and simple HPLC-UV method for determination of gallic acid in Schinopsis brasiliensis. Rev. Bras. Farmacogn. 2015, 25, 208-211. [CrossRef]

19. Fernandes, F.H.A.; Santana, C.P.; Silva, P.C.D.; Simões, M.O.d.S.; Kaneko, T.M.; Medeiros, A.C.D. Development of a sunscreen by thermal compatibility study using Schinopsis brasiliensis Engler extract as preservative. J. Therm. Anal. Calorim. 2018, 131, 753-763. [CrossRef]

20. Dorati, R.; DeTrizio, A.; Spalla, M.; Migliavacca, R.; Pagani, L.; Pisani, S.; Chiesa, E.; Conti, B.; Modena, T.; Genta, I. Gentamicin Sulfate PEG-PLGA/PLGA-H nanoparticles: Screening design and antimicrobial effect evaluation toward clinic bacterial isolates. Nanomaterials 2018, 8, 37. [CrossRef]

21. Gondim, B.L.C.; Oshiro-Júnior, J.A.; Fernanandes, F.H.A.; Nóbrega, F.P.; Castellano, L.R.C.; Medeiros, A.C.D. Plant Extracts Loaded in Nanostructured Drug Delivery Systems for Treating Parasitic and Antimicrobial Diseases. Curr. Pharm. Des. 2019, 25, 1604-1615. [CrossRef]

22. Silva, B.L.d.; Abuçafy, M.P.; Manaia, E.B.; Junior, J.A.O.; Chiari-Andréo, B.G.; Pietro, R.C.L.R.; Chiavacci, L.A. Relationship between structure and antimicrobial activity of zinc oxide nanoparticles: An overview. Int. J. Nanomed. 2019, 14, 9395-9410. [CrossRef] [PubMed] 
23. Araújo, G.M.F.; Araújo, G.M.F.; Barros, A.R.A.; Barros, A.R.A.; Oshiro-Junior, J.A.; Oshiro-Junior, J.A.; Soares, L.F.; Soares, L.F.; da Rocha, L.G.; da Rocha, L.G.; et al. Nanoemulsions Loaded with Amphotericin B: Development, Characterization and Leishmanicidal Activity. Curr. Pharm. Des. 2019, 25, 1616-1622. [CrossRef]

24. Silvestre, A.L.P.; Oshiro-Júnior, J.A.; Garcia, C.; Turco, B.O.; da Silva Leite, J.M.; de Lima Damasceno, B.P.G.; Soares, J.C.M.; Chorilli, M. Monoclonal antibodies carried in drug delivery nanosystems as a strategy for cancer treatment. Curr. Med. Chem. 2020, 27, 1-2. [CrossRef] [PubMed]

25. Chiari-Andréo, B.G.; Abuçafy, M.P.; Manaia, E.B.; da Silva, B.L.; Rissi, N.C.; Oshiro-Júnior, J.A.; Chiavacci, L.A. Drug Delivery Using Theranostics: An Overview of its Use, Advantages and Safety Assessment. Curr. Nanosci. 2019, 16, 3-14. [CrossRef]

26. Oshiro-Júnior, J.A.; Rodero, C.; Hanck-Silva, G.; Sato, M.R.; Alves, R.C.; Eloy, J.O.; Chorilli, M. Stimuli-responsive Drug Delivery Nanocarriers in the Treatment of Breast Cancer. Curr. Med. Chem. 2018, 27, 2494-2513. [CrossRef]

27. Oshiro-Júnior, J.A.; Sato, M.R.; Boni, F.I.; Santos, K.L.M.; Oliveira, T.K.; Freitas, L.M.; Fontana, C.R.; Nicholas, D.; McHale, A.; Callan, J.F.; et al. Phthalocyanine-loaded nanostructured lipid carriers functionalized with folic acid for photodynamic therapy. Mater. Sci. Eng. C 2020, 108, 110462. [CrossRef] [PubMed]

28. Zazo, H.; Colino, C.I.; Lanao, J.M. Current applications of nanoparticles in infectious diseases. J. Control. Release 2016, 224, 86-102. [CrossRef]

29. Oswaldo, F. Farmacopeia Brasileira, 5th ed.; National Health Surveillance Agency: Brasília, Brazil, 2010; Volume 1.

30. Boni, F.I.; Almeida, A.; Lechanteur, A.; Sarmento, B.; Cury, B.S.F.; Gremião, M.P.D. Mucoadhesive nanostructured polyelectrolytes complexes modulate the intestinal permeability of methotrexate. Eur. J. Pharm. Sci. 2018, 111, 73-82. [CrossRef]

31. Siyawamwaya, M.; Choonara, Y.E.; Bijukumar, D.; Kumar, P.; Du Toit, L.C.; Pillay, V. A Review: Overview of Novel Polyelectrolyte Complexes as Prospective Drug Bioavailability Enhancers. Int. J. Polym. Mater. 2015, 64, 955-968. [CrossRef]

32. Hao, J.; Fang, X.; Zhou, Y.; Wang, J.; Guo, F.; Li, F.; Peng, X. Development and optimization of solid lipid nanoparticle formulation for ophthalmic delivery of chloramphenicol using a Box-Behnken design. Int. J. Nanomed. 2011, 6, 683-692.

33. Tan, C.; Xie, J.; Zhang, X.; Cai, J.; Xia, S. Polysaccharide-based nanoparticles by chitosan and gum arabic polyelectrolyte complexation as carriers for curcumin. Food Hydrocoll. 2016, 57, 236-245. [CrossRef]

34. Griffiths, P.C.; Cattoz, B.; Ibrahim, M.S.; Anuonye, J.C. Probing the interaction of nanoparticles with mucin for drug delivery applications using dynamic light scattering. Eur. J. Pharm. Biopharm. 2015, 97, 218-222. [CrossRef] [PubMed]

35. Crucho, C.I.; Barros, M.T. Polymeric nanoparticles: A study on the preparation variables and characterization methods. Mater. Sci. Eng. 2017, 1, 771-784. [CrossRef] [PubMed]

36. Zaki, N.M.; Hafez, M.M. Enhanced antibacterial effect of ceftriaxone sodium-loaded chitosan nanoparticles against intracellular Salmonella typhimurium. AAPS PharmSciTech 2012, 13, 411-421. [CrossRef] [PubMed]

37. Polexe, R.C.; Delair, T. Elaboration of stable and antibody functionalized positively charged colloids by polyelectrolyte complexation between chitosan and hyaluronic acid. Molecules 2013, 18, 8563-8578. [CrossRef] [PubMed]

38. Jamil, B.; Habib, H.; Abbasi, S.; Nasir, H.; Rahman, A.; Rehman, A.; Bokhari, H.; Imran, M. Cefazolin loaded chitosan nanoparticles to cure multi drug resistant Gram-negative pathogens. Carbohydr. Polym. 2015, 136, 682-691. [CrossRef]

39. Avadi, M.R.; Sadeghi, A.M.M.; Mohammadpour, N.; Abedin, S.; Atyabi, F.; Dinarvand, R.; Rafiee-Tehrani, M. Preparation and characterization of insulin nanoparticles using chitosan and Arabic gum with ionic gelation method. Nanomed. Nanotechnol. 2010, 6, 58-63. [CrossRef]

40. Danaei, M.; Dehghankhold, M.; Ataei, S.; Hasanzadeh Davarani, F.; Javanmard, R.; Dokhani, A.; Khorasani, S.; Mozafari, M.R. Impact of particle size and polydispersity index on the clinical applications of lipidic nanocarrier systems. Pharmaceutics 2018, 10, 57. [CrossRef]

41. Khan, S.A.; Schneider, M. Improvement of Nanoprecipitation Technique for Preparation of Gelatin Nanoparticles and Potential Macromolecular Drug Loading. Macromol. Biosci. 2013, 13, 455-463. [CrossRef] 
42. Deshmukh, K.; Ahamed, M.B.; Deshmukh, R.R.; Pasha, S.K.K.; Bhagat, P.R. Biopolymer Composites in Electronics 3-Biopolymer Composites with High Dielectric Performance: Interface. Biopolym. Compos. Electron. 2017, 3, 27-128.

43. De Gonsalves, A.; Araujo, C.R.M.; Soares, N.A.; Goulart, M.O.F.; De Abreu, F.C. Diferentes Estrategias Para A Reticulaqao De Quitosana. Quim. Nova 2011, 34, 1215-1223. [CrossRef]

44. Bhattacharjee, S. DLS and zeta potential-What they are and what they are not? J. Control. Release 2016, 235, 337-351. [CrossRef] [PubMed]

45. Ilk, S.; Sağlam, N.; Özgen, M.; Korkusuz, F. Chitosan nanoparticles enhances the anti-quorum sensing activity of kaempferol. Int. J. Biol. Macromol. 2017, 94, 653-662. [CrossRef] [PubMed]

46. Saghiri, M.A.; Asgar, K.; Lotfi, M.; Karamifar, K.; Saghiri, A.M.; Neelakantan, P.; Gutmann, J.L.; Sheibaninia, A. Back-scattered and secondary electron images of scanning electron microscopy in dentistry: A new method for surface analysis. Acta Odontol. Scand. 2012, 70, 603-609. [CrossRef] [PubMed]

47. Gaumet, M.; Vargas, A.; Gurny, R.; Delie, F. Nanoparticles for drug delivery: The need for precision in reporting particle size parameters. Eur. J. Pharm. Biopharm. 2008, 69, 1-9. [CrossRef]

48. Petit, T.; Puskar, L. FTIR spectroscopy of nanodiamonds: Methods and interpretation. Diam. Relat. Mater. 2018, 89, 52-66. [CrossRef]

49. Vijayaraghavan, K.; Ashokkumar, T. Plant-mediated biosynthesis of metallic nanoparticles: A review of literature, factors affecting synthesis, characterization techniques and applications. J. Environ. Chem. Eng. 2017, 5, 4866-4883. [CrossRef]

50. Mauricio-Sánchez, R.A.; Salazar, R.; Luna-Bárcenas, J.G.; Mendoza-Galván, A. FTIR spectroscopy studies on the spontaneous neutralization of chitosan acetate films by moisture conditioning. Vib. Spectrosc. 2018, 94, 1-6. [CrossRef]

51. Tonhi, E.; Plepis, A.M.d.G. Obtenção e caracterização de blendas colágeno-quitosana. Quim. Nova 2002, 25, 943-948. [CrossRef]

52. Sotelo-Boyás, M.E.; Correa-Pacheco, Z.N.; Bautista-Baños, S.; Corona-Rangel, M.L. Physicochemical characterization of chitosan nanoparticles and nanocapsules incorporated with lime essential oil and their antibacterial activity against food-borne pathogens. LWT Food Sci. Technol. 2017, 77, 15-20. [CrossRef]

53. Shetty, G.R.; Rao, B.L.; Gowda, M.; Shivananda, C.S.; Asha, S.; Sangappa, Y. The preparation and characterization of silk fibroin blended with low molecular weight hydroxypropyl methylcellulose (HPMC). In AIP Conference Proceedings; AIP Publishing: Melville, NY, USA, 2018; Volume 1942, pp. 1-6.

54. Shi, S.C.; Wu, J.Y.; Huang, T.F. Raman, FTIR, and XRD study of MoS2 enhanced hydroxypropyl methylcellulose green lubricant. Opt. Quantum Electron. 2016, 48, 1-9. [CrossRef]

55. Manimekalai, P.; Dhanalaksmi, R.; Manavalan, R. Preparation and characterization of ceftriaxone sodium encapsulated chitosan nanoparticles. Int. J. App. Pharm. 2017, 9, 10-15. [CrossRef]

56. Medeiros, A.C.D.; Alencar, L.C.B.; Castro, F.D. Schinopsis brasiliensis Engl. In Medicinal and Aromatic Plants of the World, 1st ed.; Albuquerque, U.P., Patil, U., Máthé, Á., Eds.; Springer: Dordrecht, The Netherlands, 2018; Volume 38, pp. 421-429.

57. Holetz, F.B.; Pessini, G.L.; Sanches, N.R.; Cortez, A.G.; Nakamura, C.V.; Prado, B.; Filho, D. Screening Pl Medicinais 2.Pdf. Mem. Inst. Oswaldo Cruz 2002, 97, 1027-1031. [CrossRef]

58. CLSI Performance standards for antimicrobial susceptibility testing. CLSI supplement M100. In Performance Standards for Antimicrobial Susceptibility Testing. CLSI supplement M100; Clinical and Laboratory Standards Institute: Wayne, PA, USA, 2018; p. 282.

59. Liu, X.; Toprakcioglu, Z.; Dear, A.J.; Levin, A.; Ruggeri, F.S.; Taylor, C.G.; Hu, M.; Kumita, J.R.; Andreasen, M.; Dobson, C.M.; et al. Fabrication and Characterization of Reconstituted Silk Microgels for the Storage and Release of Small Molecules. Macromol. Rapid Commun. 2019, 40, 4-7. [CrossRef] [PubMed]

60. Costa, E.M.; Silva, S.; Veiga, M.; Tavaria, F.K.; Pintado, M.M. Exploring chitosan nanoparticles as effective inhibitors of antibiotic resistant skin microorganisms-From in vitro to ex vitro testing. Carbohydr. Polym. 2018, 201, 340-346. [CrossRef]

61. Abdelkader, A.; El-Mokhtar, M.A.; Abdelkader, O.; Hamad, M.A.; Elsabahy, M.; El-Gazayerly, O.N. Ultrahigh antibacterial efficacy of meropenem-loaded chitosan nanoparticles in a septic animal model. Carbohydr. Polym. 2017, 174, 1041-1050. [CrossRef] [PubMed]

62. Gupta, A.; Mumtaz, S.; Li, C.H.; Hussain, I.; Rotello, V.M. Combatting antibiotic-resistant bacteria using nanomaterials. Chem. Soc. Rev. 2019, 48, 415-427. [CrossRef] 
63. Parisi, O.I.; Scrivano, L.; Sinicropi, M.S.; Puoci, F. Polymeric nanoparticle constructs as devices for antibacterial therapy. Curr. Opin. Pharmacol. 2017, 36, 72-77. [CrossRef] [PubMed]

64. Jamil, B.; Abbasi, R.; Abbasi, S.; Imran, M.; Khan, S.U.; Ihsan, A.; Javed, S.; Bokhari, H. Encapsulation of cardamom essential oil in chitosan nano-composites: In-vitro efficacy on antibiotic-resistant bacterial pathogens and cytotoxicity studies. Front. Microbiol. 2016, 7, 1580. [CrossRef] 